\title{
CHANGES IN TAXONOMIC DIVERSITY OF UKRAINIAN MAMMALS FOR THE LAST THREE CENTURIES: EXTINCT, PHANTOM, AND ALIEN SPECIES
}

\author{
Igor Zagorodniuk \\ National Museum of Natural History, National Academy of Sciences of Ukraine \\ Bohdan Khmelnytsky St. 15, Kyiv,01030,Ukraine; E-mail: zoozag@ukr.net
}

\begin{abstract}
Changes in Taxonomic Diversity of Ukrainian Mammals for the Last Three Centuries: Extinct, Phantom, and Alien Species. - Zagorodniuk, I. - The species composition in the mammal fauna of Ukraine for the last three centuries has been analyzed. Estimates of species richness were presented for families, superfamilies, suborders and orders. The data were grouped into superorders: Glires ( 58 species, 52 of them in the modern fauna), Lipotyphla $(14,12)$, Chiroptera $(29,28)$, Ferae $(23,21)$, Ungulata $(22,18)$. The modern mammal fauna includes 131 species (among them 23 alien species); in addition, 15 species became extinct during the last 300 years. Thus, the complete list of Ukrainian mammal fauna (including extinct mammals) includes 146 species. There are also 9 "phantom" species which were not included in diversity indices or fauna changes calculations. The index of fauna changes (IFR) is $15.4 \%$; it has the maximum in Ungulata (42.9\%) and Ferae $(23.5 \%)$, and the minimum in Lipotyphla $(7.1 \%)$ and Chiroptera $(5.6 \%)$. The rates of fauna changes are increasing over time, and they reached the highest values in the last few decades.
\end{abstract}

Key words: mammals, taxonomic richness, extinction, alien species, Ukraine.

Зміни таксономічного різноманіття ссавців України за три останніх століття: вимерлі, чужорідні та фантомні види. - Загороднюк, І. - Проведено аналіз видового складу ссавців, відомих у складі фауни України впродовж останніх трьох століть. Оцінки видового багатства наведено за родинами, над родинами, підрядами й рядами. Весь матеріал згруповано за надрядами: Glires (58 видів, 52 з них у сучасній фауні), Lipotyphla $(14,12)$, Chiroptera $(29,28)$, Ferae $(23,21)$, Ungulata $(22,18)$. У загальному списку сучасної теріофауни (131 види) є 123 види вихідного переліку, з яких 15 вимерли, та 23 чужорідних видів. Повний список фауни (включно з вимерлими) включає 146 видів. У переліку фауни є також 9 «фантомних» видів, які не включено у розрахунки показників різноманіття або змін фауни. Індекс ротації фауни в цілому склав IFR $=15,4$ \%, найбільшим він є у унгулят $(42,9 \%)$ та хижих $(23,5$ \%), найменший він у комахоїдних $(7,1 \%)$ та рукокрилих $(5,6 \%)$. Темпи змін фауни наростають у часі і $\epsilon$ найбільшими в останні кілька десятиліть.

Ключові слова: ссавці, таксономічне багатство, вимирання, чужорідні види, Україна.

\section{Introduction}

The species composition of mammal fauna is well known and stable. By present, the mammal fauna of Ukraine is studied in details, including faunistic description of all geographical regions as well as taxonomic revision of all taxonomic groups (Zagorodniuk, Emelianov, 2012). In spite of this, fauna on regional levels (regional faunas) is very dynamic, and it continuously changes. Moreover, such changes can be considered as a normal process, which is an immanent property of biodiversity (Protasov, 2002; Zagorodniuk, Rizun, 2012). Such changes were analyzed in depth in many studies of mammal fauna of Ukraine (e.g. Sokur, 1961; Zagorodniuk, 2010 b).

Earlier fauna changes were recorded and considered in the analysis of large time intervals (e.g., changes during the Holocene or the Common Era) (Pidoplichko, 1951; Kirikov, 1966, 1983), but now such changes occur within the timespan of a single generation (Zagorodniuk, 2006; Bobrov et al., 2008). An important measure in monitoring, protection and sustainable use of fauna, according to "Convention on Biological Diversity" (Convention..., 2014), is compiling the taxonomic lists of fauna groups (including the mammal fauna of Ukraine) and tracing changes in these lists. 
The main goal of this paper is to summarize all the data on species richness of mammals in Ukraine as well as to estimate scopes of their historical changes and compare separate groups by species richness indices and temporal changes.

\section{Analytical remarks}

The paper is based on the results of revisions of the mammal fauna checklist of Ukraine which was presented earlier (Zagorodniuk, 2008; Zagorodniuk, Emelianov, 2012). The previous lists of species were presented in 1984 (Kryhanovsky, Emelianov, 1984) and 1965 (Korneyev, 1965). In the mammals taxonomy ranks higher than family correspond to the review by McKenna and Bell (1997), with some corrections (Wilson, Reeder, 2005; Amrine-Madsen et al., 2003; Asher et al., 2009 etc.). It is important to note that the analysis of fauna changes should be conducted with clear distinction between real changes in fauna composition and subjective changes of researcher's views on fauna composition (Zagorodniuk, 2010 a). Variable part of the species list that was mentioned in different lists of the fauna of Ukraine, was earlier discussed (Zagorodniuk, $2010 \mathrm{~b}$ ).

List of species was indexed using several estimators. Earlier the author (Zagorodniuk, 2007) proposed to distinguish in the fauna list seven species groups: "normal" (N), "sibling" (S), "aliens" (A), "rare" (R), "extinct" (E), "phantom" (F), and "mistake" (M) which were described in details by Zagorodniuk and Emelianov (2008). In this paper, four categories of species considered:

- "ini" is a species from a previous list corresponding to the state of "reconstructed fauna", i. e. fauna associated with the $10^{\text {th }}-17^{\text {th }}$ centuries (suggestions on some large-size mammals see in: Sokur, 1961; other reconstructions see in: Zagorodniuk, 2007 b; Dulitsky, 2010). Unaltered part of this list forms the "basal" list of modern fauna;

- "ext" is a species known in historical times and extinct during the last 300 years. Detailed analysis was published by I. Sokur (1961) and later it was specified for ungulates (Zagorodniuk, 1999) and carnivores (Zagorodniuk, 2001). Some species are often listed as living, but they are probably extinct (e.g., Eliomys quercinus, Monachus monachus, Bison bonasus) ${ }^{1}$;

- "adv" is an alien species, including acclimatized species (introduced in nature or domestic animals regularly occurring in the wild) and species appeared in Ukraine due to natural expansion. Alien mammals of Ukraine were analyzed in a special review (Zagorodniuk, 2006). There are many species for which the alien status was only suggested or recently considered (e.g., Plecotus austriacus, Lagurus lagurus, Mustela eversmanni) (Bobrov et al., 2008; Zagorodniuk, 2010); There are many species with the status of "local invaders": their ranges were significantly changed within the territory of Ukraine (e.g., Pipistrellus kuhlii and Myodes glareolus);

- ,pha" is a phantom species presence of which in the fauna is unclear or its presence in the modern fauna is not argued. Among such species there are species with phantom status during all times (e.g., Balaenoptera acutorostrata and Capreolus pygargus), species with unproved presence in the modern fauna (for ex., Eliomys quercinus, see category "ext" above), alien species known from localities near Ukraine (e.g., Procyon lotor). In all fauna richness estimations, the number of phantom species was not used in any summations of species.

These four categories were used to estimate the fauna richness and indexes of fauna changes. Main groups of species that were calculated and analyzed in this paper are the following:

- "basal list" is a part of group "ini", without extinct species:

bas $=i n i-e x t$

- "modern list" is the " basal list" added by the alien species

$\bmod =b a s+a d v$ group:

- "complete species list" (CSL) is the "modern list" added by

$(\bmod =i n i-e x t+a d v)$ extinct species (total list is TSL $=\mathrm{CSL}+$ pha):

$C S L=\bmod +$ ext

$(C S L=i n i+a d v)$

\footnotetext{
${ }^{1}$ According to the "Red Book of Ukraine", Bison bonasus has status 'extinct in the wild" (Red..., 2009), whilst researchers describe viable populations in nature (Parnikoza et al., 2010). Monachus monachus is considered as completely extinct in the "Red Book of Ukraine" (Red..., 2009) and special publications (Gladilina et al., 2013).
} 
For estimation of the fauna changes, the index earlier proposed for analysis of changes in local or regional fauna lists was used (Zagorodniuk, $2007 \mathrm{a}-\mathrm{b}$ ). The Index of Fauna Rotation (IFR) is the estimator of changes in fauna by comparison of initial and modern lists of species. By default, an "initial" list is a species list for the regional fauna, reconstructed for the period of about the mid- $18^{\text {th }}$ to the mid- $19^{\text {th }}$ centuries, i.e. the time of detailed descriptions of fauna, stabilization of nomenclature and creation of systematical collections. In the same time, there were no large and essential changes in natural ecosystems which happened later (well-developed transport networks, canals, forest belts, agricultural lands etc.) and provoked many changes in fauna, including extinctions and expansions or invasions (Zagorodniuk, 2013). Therefore, IFR is an average percent of species, which were involved in rotation (extinct + alien), in relation to the initial composition of fauna:

$$
\begin{aligned}
& \mathrm{IFR}=\left[\left(\mathrm{N}_{e x t}+\mathrm{N}_{a d v}\right) / 2\right] / \mathrm{N}_{i n i} * 100(\%), \\
& \text { where } \mathrm{N}_{e x t} \text { is ,ext”, } \mathrm{N}_{a d v} \text { is ,,adv", } \mathrm{N}_{i n i} \text { is ,,ini" groups (described above). }
\end{aligned}
$$

\section{State of research of mammal fauna changes in Ukraine}

In general, the Ukrainian mammal fauna is poorly studied in the context of its historical changes. It can be explained by predominance of unchangeable paradigm in faunal investigations: most of studies were aimed to update faunal data, expanding the list of known species. This approach become a main one in creating of fauna lists for many nature reserves, administrative regions and fauna lists for Ukraine in a whole. There were many situations when researchers listed extinct and alien species, phantom species and a few synonyms of the single species in the same fauna description, or listed names of species and species group (species s. 1.) as two different species ${ }^{2}$. As a result, some fauna lists were unnecessarily expanded, whereas the analyses of fauna changes were often ignored.

A brief review of publications in this area is listed below.

Analysis of the fauna in a whole. The first researcher who paid special attention to this issue from the viewpoint of historical biogeography was I. Pidoplichko $(1936,1951)$. In the same time, some researchers paid their attention to the changes of mammal fauna due to changes of landscapes, mainly in the steppe zone (Sakhno, 1938, 1969), and to changes caused by direct human impact, including extirpation of some species and introduction of another ones (Sokur, 1961). The first review of alien mammal species in Ukraine was published only in 2006 (Zagorodniuk, 2006).

Analysis by regions. A relatively well studied region is the South-East of Ukraine because this region is undergoing major transformations as a whole, and its fauna dramatically changed that has been the subject of many studies. The map that demonstrates the changes of mammal fauna by regions was published earlier (fig. 5 in: Zagorodniuk, $2010 \mathrm{~b}$ ). The main research concentrated on fauna changes in the South of and East of Ukraine as the most transformed regions of Ukraine due to human-induced destruction of steppe and coastal ecosystems.

Thus, in the South, the historical changes of mammal fauna in the Askania-Nova Biosphere Reserve were analyzed by I. Polishchuk $(2003,2008)$. In sum, the initial list of mammal fauna (data for the beginning of the $20^{\text {th }}$ century) includes 22 species; by present 5 of them became extinct, and at least 6 new species colonized the Askania-Nova. In addition, there are 13 synanthropic species in the adjacent areas (Polishchuk, 2003). A detailed analysis of mammal fauna changes in the Crimea during a long-time period (including Pleistocene and Holocene) was conducted by A. Dulitskiy (2010). One of the natural reserved areas, the "Kamiani Mohyly", was chosen as a model area for evaluation of the historical changes of fauna, and the rate of such changes was estimated as $46 \%$ per century

\footnotetext{
${ }^{2}$ For example, in many modern reviews there are such extinct species as Miniopterus scheibersii, Eliomys quercinus, Monachus monachus (Red Book of Ukraine, 2009 etc.). Synonyms as separate species are listed from time to time in different regional lists of fauna as well as in the redlists, as example: Mycrotus tatricus and Terricola tatricus in the list of protected animals of Ukraine (Parnikoza et al., 2005). The list of serious problems also includes the issues of species identification as well as desire of some investigators to find some new species that was resulted in wide list of phantom species (Zagorodniuk, 2010); among them in Ukraine there are Erinaceus europaeus, Sorex isodon, Myotis ikonnikovi, Rhinolophus euryale, Tadarida teniotis, Capreolus pygargus, etc.
} 
(Zagorodniuk, 2007 a). Using this algorithm, the calculation for the Askania-Nova demonstrates the same result: the list of mammal fauna changed in about $50 \%$ for the last century.

A great attention was also paid to the East of Ukraine. Descriptions of mammal fauna changes in the Luhansk Region, the easternmost part of Ukraine, were published in several articles by I. Sakhno, as in relation to game mammals (Sakhno, Symonov, 1956), as in relation to the fauna in a whole (Sakhno, 1969). Later, a general list of mammal fauna of the east Ukraine was compiled with differentiation by the status of species, including categories of extinction, acclimatization, alien, rarity, etc. (Zagorodniuk, 2006). In addition, based on comparison with data by I. Sakhno (Sakhno, 1969), the rate of fauna changes was assessed as IFR $=27 \%$ per century (Zagorodniuk, 2012).

Using this algorithm, the study was conducted to analyze the long-term changes in fauna of two other regions: Slobozhanska Ukraine (northeast Ukraine) and Podillia (central-western part of the country). The analysis of the fauna of Slobozhanschyna showed IFR $=22 \%$ for 160 years, or IFR 100 $=14 \%$ (Zagorodniuk, $2010 \mathrm{a}$ ). The same analysis for mammal fauna of Podillia showed that index of fauna rotation (in 100 years scale) is IFR $_{100}=12 \%$ (Zagorodniuk, Pirkhal, 2013).

Analysis by taxonomic and ecological groups. One of the earliest research was the analysis of changes in the bat fauna of Ukraine which was based on the data on changes in species weights in the collections of different times (Zagorodniuk, Tkach, 1996) and changes of population abundance and species ranges in some bat species (Zagorodniuk, Negoda, 2001; Godlevskaya, 2012). Similar analysis was conducted for ungulates (Zagorodniuk, 1999), carnivores (Rozhenko, Volokh, 2000; Zagorodniuk, 2001), semi-aquatic mammals (Panov, 2002) and all pairs of mammal sibling species known in the Ukrainian fauna (Zagorodniuk, 2005, 2010 b).

\section{Analysis of taxonomic groups}

\section{Superorder Glires}

There are 52 species in modern fauna list. The complete list includes 58 species $(\mathrm{CSL}=58)$, 6 of which are extinct and another 7 are alien species (Table 1). One species (Eliomys quercinus), which is summed in the "extinct" group, at the same time has the status of "phantom" species.

In modern fauna of Ukraine, this superorder is presented by two orders (Leporiformes and Muriformes) and 13 families (from Leporidae to Myocastoridae). The most diverse group is the superfamily Muroidea (32 species, among them there are 5 alien). The poorest group is the order Leporiformes (Lagomorpha) that includes 4 species in the complete list (with 1 extinct and 1 alien species).

1.1. Order Leporiformes (= Lagomorpha auct.) in the Ukrainian fauna includes 4 species in CSL, among them there are 1 extinct and 1 alien species (Oryctolagus cuniculus). In modern fauna there are only 3 species of the family Leporidae; a single species of the family Ochotonidae (Ochotona pusilla) became extinct in the $18^{\text {th }}$ or $19^{\text {th }}$ century ${ }^{3}$ (Pidoplichko, 1934).

1.2. Order Muriformes (= Rodentia auct.) is the richest order of mammals: in the Ukrainian fauna CSL $=54$ species of 4 suborders. 49 species are represented in the modern fauna, 5 species are extinct in historical times, 6 species are alien. The greatest number of extinctions was recorded in suborder Sciuromorpha (4 of 15 extinct species in full CSL). The greatest number of newly recorded species is in suborder Murimorpha (5 new species among 7 alien species in the CSL of Glires).

1.2.1. Suborder Sciuromorpha (TLS $=9 \mathrm{sp}$.) is represented by two families, Sciuridae and Gliridae. The small species richness is combined with a great reduction of species number: 4 species extinct (3 extinct species and another "phantom" species which was not recorded in 40 years, Eliomys quercinus) (Zagorodniuk, 2009).

1.2.2. Suborder Castorimorpha (CSL $=1 \mathrm{sp}$., Castor fiber). During the $19^{\text {th }}-20^{\text {th }}$ centuries this group was in status «threatened», but in the latest two decades the beaver demonstrates intensive growth in abundance and considerable expansion of its range in Ukraine.

\footnotetext{
${ }^{3}$ Vernacular name of this species ("zemliany zaichyk" = "earth leveret" or "terrestrial little hare") later "transferred" to another species, the great jerboa (Allactaga major).
} 
Table 1. Values of taxonomic richness of mammals of the superorder Glires in the fauna of Ukraine

Таблиця 1. Показники таксономічного багатства ссавців надряду Glires, представлених у фауні України

\begin{tabular}{|c|c|c|c|c|c|c|c|}
\hline Taxa (orders and families)* & $\begin{array}{l}\text { Ukrainian } \\
\text { name }\end{array}$ & Initial & Extinct & Alien & $\begin{array}{l}\text { Mod- } \\
\text { ern }\end{array}$ & $\begin{array}{l}\text { Com- } \\
\text { plete } \\
\text { list }\end{array}$ & $\begin{array}{c}\text { Phan- } \\
\text { tom }\end{array}$ \\
\hline order Leporiformes (Lagomorpha) & Зайцеподібні & 3 & 1 & 1 & 3 & 4 & 0 \\
\hline Leporidae Fischer, 1817 & зайцеві & 2 & 0 & 1 & 3 & 3 & 0 \\
\hline Ochotonidae Thomas, 1896 & пискухові & 1 & 1 & 0 & 0 & 1 & 0 \\
\hline order Muriformes (Rodentia) & Мишоподібні & 48 & 5 & 6 & 49 & 54 & (1) \\
\hline suborder Sciuromorpha & Вивірковиді & 13 & 4 & 0 & 9 & 13 & (1) \\
\hline Sciuridae Fischer, 1817 & вивіркові & 9 & 3 & 0 & 6 & 9 & 0 \\
\hline Gliridae Muirhead, 1819 & вовчкові & 4 & 1 & 0 & 3 & 4 & (1) \\
\hline suborder Castorimorpha & Бобровиді & 1 & 0 & 0 & 1 & 1 & 0 \\
\hline Castoridae Hemprich, 1820 & боброві & 1 & 0 & 0 & 1 & 1 & 0 \\
\hline suborder Murimorpha (Myomorpha) & Мишовиді & 34 & 1 & 5 & 38 & 39 & 0 \\
\hline superfamily Dipodoidea & стрибакуваті & 7 & 1 & 0 & 6 & 7 & 0 \\
\hline Sicistidae Allen, 1901 & мишівкові & 4 & 0 & 0 & 4 & 4 & 0 \\
\hline Allactagidae Vinogradov, 1925 & тушканові & 2 & 1 & 0 & 1 & 2 & 0 \\
\hline Dipodidae Fischer, 1817 & стрибакові & 1 & 0 & 0 & 1 & 1 & 0 \\
\hline superfamily Muroidea (Myodonta) & мишуваті & 27 & 0 & 5 & 32 & 32 & 0 \\
\hline Spalacidae Gray, 1821 & сліпакові & 5 & 0 & 0 & 5 & 5 & 0 \\
\hline Muridae Illiger, 1811 & мишеві & 7 & 0 & 3 & 10 & 10 & 0 \\
\hline Cricetidae Fischer, 1817 & хом'якові & 2 & 0 & 0 & 2 & 2 & 0 \\
\hline Arvicolidae Gray, 1821 & щурові & 13 & 0 & 2 & 15 & 15 & 0 \\
\hline suborder Hystricomorpha & Їжатцевиді & 0 & 0 & 1 & 1 & 1 & 0 \\
\hline Myocastoridae Ameghino, 1904 & нутрієві & 0 & 0 & 1 & 1 & 1 & 0 \\
\hline Total of Glires & Гризуни & 51 & 6 & 7 & 52 & 58 & (1) \\
\hline
\end{tabular}

* In parentheses there are traditional un-standardized names.

1.2.3. Suborder Murimorpha (= Myomorpha) $(\mathrm{CSL}=39 \mathrm{sp}$.). The most diverged suborder among mammals of Ukraine in a whole. There are 34 species in the basic (initial) list, 1 of them (Pygeretmus pumilio Kerr, 1792) became extinct and 5 alien species appeared (Muroidea). The suborder is represented by two superfamilies: Dipodoidea (CSL $=7$ sp., 1 ext., 0 aliens) with families Sicistidae (4 modern species), Allactagidae (1 sp.) and Dipodidae (1 sp.); superfamily Muroidea (= Myodonta, CSL = 32 sp., 0 ext., 5 aliens) includes families Spalacidae (5 sp.), Muridae (10 sp.), Cricetidae (2 sp.) and Arvicolidae (15 modern species).

1.2.4. Suborder Hystricomorpha (CSL $=1$ sp., 0 ext., 1 aliens). An alien group in a whole, which is represented by the single species from the family Myocastoridae (one species of introduced and domestic mammal, Myocastor coypus). Another species, Cavia porcellus (Caviidae) that was included in the fauna list earlier, here is excluded from the list of fauna because of absence of clear indications of its presence in the wild nature in Ukraine.

Index of fauna changes for Glires is:

$\operatorname{IFR}=[(6+7) / 2] / 51 * 100(\%)=12.7 \%$.

Such high value appears due to large number of extinct Sciuromorpha (4 extinct species) and large portion of alien species of Muroidea ( 5 alien species). 
Table 2. Values of taxonomic richness of mammals of superorder Lipotyphla represented in the fauna of Ukraine Таблиця 2. Показники таксономічного багатства ссавців надряду Lipotyphla, представлених у фауні України

\begin{tabular}{c|l|c|c|c|c|c|c}
\hline Таха (orders and families) & $\begin{array}{l}\text { Ukrainian } \\
\text { name }\end{array}$ & Initial & Extinct & Alien & $\begin{array}{c}\text { Mod- } \\
\text { ern }\end{array}$ & $\begin{array}{c}\text { Com- } \\
\text { plete } \\
\text { list }\end{array}$ & $\begin{array}{c}\text { Phan- } \\
\text { tom }\end{array}$ \\
\hline order Soriciformes (Insectivora) & Мідицеподібні & 14 & 2 & 0 & 12 & 14 & $(2)$ \\
Erinaceidae Fischer, 1814 & іжакові & 2 & 1 & 0 & 1 & 2 & $(1)$ \\
Talpidae Fischer, 1814 & кротові & 2 & 0 & 0 & 2 & 2 & 0 \\
Soricidae Fischer, 1814 & мідицеві & 10 & 1 & 0 & 9 & 10 & $(1)$ \\
Tота丿 of Lipotyphla & Ліпотифли & 14 & 2 & 0 & 12 & 14 & $(2)$ \\
\hline
\end{tabular}

\section{Superorder Lipotyphla}

One of the poorest superorders in the Ukrainian fauna which is represented by 12 species in modern fauna. The total list includes 2 extinct and 2 phantom species (Table 2). Three families commonly considered as a single order Insectivora or divided into two orders: Soriciformes (shrews and moles) and Erinaceiformes (hedgehogs). In this review, the group is considered as order Soriciformes, similarly to our previous review (Zagorodniuk, Emelianov, 2012).

2.1. Order Soriciformes (Insectivora auct.) includes three families, Erinaceidae $(\mathrm{CSL}=2)$, Talpidae $(\mathrm{CSL}=2)$, and Soricidae $(\mathrm{CSL}=10)$. Similarly to data on the superorder, the initial list includes 14 species, 2 of which were extinct. There are 2 phantom species: Sorex caecutiens (likely present) and S. satunini (probably extinct). Status of one species (Crimean Sorex (minutus) cf. volnuchini) requires additional study (Zagorodniuk, 1996); description of Sorex cf. isodon as a new species for the fauna of Ukraine (Mezhzherin, 1995) is assumed in the result of false identification of the common shrew (Zagorodniuk, 1996).

Index of fauna changes for Lipotyphla is IFR $=[(2+0) / 2] / 14 * 100=7.1 \%$.

Among insectivores, there is a great portion of problematic taxa: an extinct species (Sorex satunini) and another probably extinct species (Hemiechinus auritus) (Shevchenko, 2008 etc.). In addition, there are two phantom species (Erinaceus europaeus and Sorex isodon) that were not included into our Ukrainian mammal fauna checklist (Zagorodniuk, Emelianov, 2012).

\section{Superorder Chiroptera}

A rich in species group in the Ukrainian fauna, which is represented by 28 modern species, $\mathrm{TSL}=32$ species $(\mathrm{CSL}=29 ;+3$ phantom species). In the complete list of species, there are 1 extinct and 2 alien species. The species list includes 3 families of one order (Vespertilioniformes).

3.1. Order Vespertilioniformes (Chiroptera auct.) includes 28 modern species, among them there are such families as Vespertilionidae $(\mathrm{CSL}=27$ species), Molossidae (CSL $=0,1$ phantom) and Rhinolophidae (CSL $=2$ species). The greatest portion of species diversity refers to Vespertilionidae, the central family of suborder Vespertilionimorpha. In the total species list, there are 1 extinct, 2 alien and 3 phantom species: TSL $=32$ species $(29 \mathrm{CSL}+3$ pha).

3.1.1. Suborder Vespertilionimorpha (Yangochiroptera) is presented by 2 families, Vespertilionidae (26 modern +1 extinct +1 phantom species) and Molossidae (only 1 phantom species, Tadarida teniotis, recorded in the Crimea: Uhrin et al., 2009). The family Vespertilionidae is the most abundant family of mammals in Ukraine in a whole.

3.1.2. Suborder Pteropodimorpha (Yingochiroptera) is the most exotic family presented by 2 horseshoe bat species from family Rhinolophidae ( +2 phantom species). Identification of both phantom species (Rhinolophus euryale and mehelyi) (Dulitskiy et al., 2001) was considered as an erroneous identification of young Ph. ferrumequinum (Zagorodniuk et al., 2002).

Index of fauna changes for Chiroptera is: IFR $=[(1+2) / 2] / 27 * 100=5.6 \%$. 
Table 3. Values of taxonomic richness of mammal superorder Chiroptera presented in the fauna of Ukraine Таблиця 3. Показники таксономічного багатства ссавців надряду Chiroptera, представлених у фауні України

\begin{tabular}{c|l|c|c|c|c|c|c}
\hline Tаха (orders and families) & $\begin{array}{l}\text { Ukrainian } \\
\text { name }\end{array}$ & Initial & Extinct & Alien & $\begin{array}{c}\text { Mod- } \\
\text { ern }\end{array}$ & $\begin{array}{c}\text { Com- } \\
\text { plete } \\
\text { list }\end{array}$ & $\begin{array}{c}\text { Phan- } \\
\text { tom }\end{array}$ \\
\hline order Vespertilioniformes (Chiroptera) & лиликоподібні & 27 & 1 & 2 & 28 & 29 & $(3)$ \\
suborder Vespertilionimorpha & лиликовиді & 25 & 1 & 2 & 26 & 27 & $(1)$ \\
Vespertilionidae Gray, 1821 & лиликові & 25 & 1 & 2 & 26 & 27 & 0 \\
Molossidae Gervais, 1855 & молосові & 0 & 0 & 0 & 0 & 0 & $(1)$ \\
suborder Pteropodimorpha & крилановиді & 2 & 0 & 0 & 2 & 2 & $(2)$ \\
Rhinolophidae Gray, 1825 & підковикові & 2 & 0 & 0 & 2 & 2 & $(2)$ \\
Total of Chiroptera & & 27 & 1 & 2 & 28 & 29 & $(3)$ \\
\hline
\end{tabular}

This group includes a great portion of problematic taxa, including 3 phantom species (Tadarida teniotis, Rhinolophus euryale and Rhinolophus mehelyi) and at least 4 pairs (or groups) of sibling and cryptic species (Myotis "mystacinus", Myotis "myotis", Plecotus "auritus", Pipistrellus "pipistrellus") (Zagorodniuk, Emelianov, 2012). Also, there is one extinct species (Miniopterus schreibersii) and two alien species (Plecotus austriacus and Pipistrellus kuhlii). The same status of alien species was suggested for Pipistrellus pygmaeus, because all of its known summer (maternal) colonies were found in artificial shelters only (Zagorodniuk, Korobchenko, 2008).

\section{Superorder Ferae (Carnivora sensu lato)}

Carnivorans are one of the most diverse groups of mammals in Ukraine: in the complete list there are 23 species of 6 families. Among them, there are 21 species from 4 families in modern fauna (3 Felidae, 6 Canidae, 1 Ursidae, and 11 Mustelidae). There is 1 phantom species (Procyon lotor), known in adjacent areas (Bobrov et al., 2008), but never supported by reliable data from Ukraine (Zagorodniuk, 2006). Status of Canis aureus as "alien" is problematic, and this species can be reclassified as aborigine species that was absent in Ukraine during the few last centuries ${ }^{4}$.

4.1. Order Caniformes (= Carnivora auct.) is the only order of Ferae in the wild fauna of Ukraine.

4.1.1. Suborder Felimorpha (= Feliformia) $(\mathrm{CSL}=3 \mathrm{sp}$.). There are 3 species of family Felidae: two aboriginal and rare species, and one alien species (the domestic cat, Felis catus).

4.1.2. Suborder Canimorpha (= Caniformia) $(\mathrm{CSL}=20 \mathrm{sp}$.) is the most abundant group, represented by 19 species in modern fauna of Ukraine ( 2 extinct, 5 alien, and 1 phantom). The most abundant families are Canidae ( 6 species in modern fauna; no extinct and 3 alien) and Mustelidae (11 species; 1 extinct and 2 alien). Family Ursidae is represented by 1 living species, and Phocidae ${ }^{5}$ is represented by 1 species (Monachus monachus) extinct in the nearest past.

Index of fauna changes in Ferae is IFR $=[(2+6) / 2] / 17 * 100=23.5 \%$.

This group demonstrates great changes in species composition (Zagorodniuk, 2001), and IFR is one of the largest. Among this group, there are 2 extinct species (Monachus monachus, Gulo gulo), 6 alien species (Felis catus, Nyctereutes procyonoides, Canis familiaris, C. aureus, Neovison vison, Mustela eversmanni), and one phantom species (Procyon lotor, also alien).

\footnotetext{
${ }^{4}$ The golden jackal (Canis aureus) was not registered in Ukraine during the last 300 years, but it was mentioned in the old Cossack chronicles ( $17^{\text {th }}$ century), so the status of jackal may be reclassified in future from "alien" to "restored" (Zagorodniuk, 2014). However, Ukrainian experts firmly stated: "In prehistoric times the golden jackal never inhabited Ukraine that is proved by absence of its paleozoological remains in this area" (Roženko, Volokh, 2010).

${ }^{5}$ Sometimes, information about new pinnipeds appears (Halichoerus grypus, Callorhinus ursinus etc.) (Gladilina et al., 2013 etc.), but in all cases those are rather separate individuals than stable breeding groups.
} 
Table 4. Values of taxonomic richness of mammal superorder Ferae presented in the fauna of Ukraine Таблиця 4. Показники таксономічного багатства ссавців надряду Ferae, представлених у фауні України

\begin{tabular}{c|l|c|c|c|c|c|c}
\hline Таха (orders and families) & $\begin{array}{l}\text { Ukrainian } \\
\text { name }\end{array}$ & Initial & Extinct & Alien & $\begin{array}{c}\text { Mod- } \\
\text { ern }\end{array}$ & $\begin{array}{c}\text { Com- } \\
\text { plete } \\
\text { list }\end{array}$ & $\begin{array}{c}\text { Phan- } \\
\text { tom }\end{array}$ \\
\hline order Caniformes (Carnivora auct.) & псоподібні & 17 & 2 & 6 & 21 & 23 & $(1)$ \\
suborder Felimorpha (Feliformia) & котовиді & 2 & 0 & 1 & 3 & 3 & 0 \\
Felidae Fischer, 1817 & котові & 2 & 0 & 1 & 3 & 3 & 0 \\
suborder Canimorpha (Caniformia) & псовиді & 15 & 2 & 5 & 18 & 20 & $(1)$ \\
superfamily Canoidea & псуваті & 3 & 0 & 3 & 6 & 6 & 0 \\
Canidae Fischer, 1817 & псові & 3 & 0 & 3 & 6 & 6 & 0 \\
superfamily Musteloidea (Arctoidea) & мустелуваті & 12 & 2 & 2 & 12 & 14 & $(1)$ \\
Ursidae Fischer, 1817 & ведмедеві & 1 & 0 & 0 & 1 & 1 & 0 \\
Phocidae Gray, 1821 & тюленеві & 1 & 1 & 0 & 0 & 1 & 0 \\
Procyonidae Gray, 1825 & ракунові & 0 & 0 & $(1)$ & 0 & 0 & $(1)$ \\
Mustelidae Fischer, 1817 & мустелові & 10 & 1 & 2 & 11 & 12 & 0 \\
Total оf Ferae & & 17 & 2 & 6 & 21 & 23 \\
\hline
\end{tabular}

\section{Superorder Ungulata (sensu lato)}

In modern fauna of Ukraine there are 17 species, including 7 alien species (14 species in the initial list -4 extinct species). In the complete species list (CSL) of ungulates there are 21 species that represent 3 orders: Equiformes (perissodactyls), Balaeniformes (cetaceans), Cerviformes (artiodactyls). Two species are phantom: Balaenoptera acutorostrata and Capreolus pygargus.

5.1. Order Equiformes (= Perissodactyla auct.) is presented by a single family (Equidae). There were at least two extinct species (besides the domestic horse, Equus caballus), one of them was extinct (E. hemionus) and another one extinct in the wild (Equus ferus), but populations of both species were restored in Ukraine due to creation of new populations in reserved areas (e.g., Yasinetskaya, Zharkikh, 2003; Vishnevskiy, Kotlyarov, 2008).

5.2. Order Balaeniformes (= Cetacea auct.) is a group with stable species composition. There are three dolphin species represented by two different families, Delphinidae $(2 \mathrm{sp}$.) and Phocoenidae (1 sp.), and one phantom species of baleen whales (Balaenoptera acutorostrata), which may be considered as extinct in the Black Sea during the last few centuries or never existing in the fauna of Ukraine (Dulitskiy, 2001; Zagorodniuk, Emelianov, 2012).

5.3. Order Cerviformes (= Artiodactyla auct.) is a group with the most dynamic species composition. Many species were extinct but restored during the latest centuries (Sokur, 1961; Zagorodniuk, 1999): there are 4 extinct and 7 alien species (Table 5). The greatly changed family is the Bovidae ( $5 \mathrm{ini}-3 \mathrm{ext}+5 \mathrm{adv}), \mathrm{CSL}=10$, index of rotation is $80 \%(!)$. Status of Capreolus pygargus is ambiguous: earlier it was considered as a probably extinct species (Zagorodniuk, 2002), however, recently its presence was confirmed by genetic signs (Plakhina et al., 2014), but natural history of this local population in the Samara forest remains uncertain.

In total, index of fauna changes for Ungulates is:

IFR $=[(4+8) / 2] / 14 * 100=42.9 \%$.

In the fauna of Ukraine, there are 3 completely extinct ungulate species (Bos primigenius, Saiga tatarica, Rupicapra rupicapra), 1 extinct in the wild (Bison bonasus), 8 alien (Equus caballus, Dama dama, Cervus nippon, Bos taurus, Bubalus bubalis, Capra hircus, Ovis musimon, Ovis aries), and one phantom species (Capreolus pygargus). Status of all domesticated species is mixed because of the presence of wild and domesticated forms in the fauna list (e.g., Equus caballus s. 1.). 
Table 5. Values of taxonomic richness of mammals of Ungulate orders represented in the fauna of Ukraine Таблиця 5. Показники таксономічного багатства ссавців з групи Ungulata, представлених у фауні України

\begin{tabular}{|c|c|c|c|c|c|c|c|}
\hline Taxa (orders and families)* & $\begin{array}{l}\text { Ukrainian } \\
\text { name }\end{array}$ & Initial & Extinct & Alien & $\begin{array}{c}\text { Mod- } \\
\text { ern }\end{array}$ & $\begin{array}{c}\text { Com- } \\
\text { plete } \\
\text { list }\end{array}$ & $\begin{array}{c}\text { Phan- } \\
\text { tom }\end{array}$ \\
\hline order Equiformes (Perissodactyla auct.) & Конеподібні & 2 & 0 & 1 & 3 & 3 & 0 \\
\hline Equidae Gray, 1821 & коневі & 2 & 0 & 1 & 3 & 3 & 0 \\
\hline order Balaeniformes (Cetacea auct.) & Китоподібні & 3 & 0 & 0 & 3 & 3 & (1) \\
\hline suborder Delphinimorpha (Odontoceti) & дельфіновиді & 3 & 0 & 0 & 3 & 3 & 0 \\
\hline Delphinidae Gray, 1821 & дельфінові & 2 & 0 & 0 & 2 & 2 & 0 \\
\hline Phocoenidae Gray, 1825 & фоценові & 1 & 0 & 0 & 1 & 1 & 0 \\
\hline suborder Balaenimorpha (Mysticeti) & китовиді & 0 & 0 & 0 & 0 & 0 & (1) \\
\hline Balaenopteridae Gray, 1864 & смугачеві & 0 & 0 & 0 & 0 & 0 & (1) \\
\hline order Cerviformes (Artiodactyla auct.) & Оленеподібні & 9 & 4 & 7 & 12 & 16 & (1) \\
\hline Suidae Gray, 1821 & свиневі & 1 & 0 & 0 & 1 & 1 & 0 \\
\hline Cervidae Goldfuss, 1820 & оленеві & 3 & 1 & 2 & 4 & 5 & (1) \\
\hline Bovidae Gray, 1821 & бикові & 5 & 3 & 5 & 7 & 10 & 0 \\
\hline Total of Ungulata & Унгуляти & 14 & 4 & 8 & 18 & 22 & $(2)$ \\
\hline
\end{tabular}

\section{Overall fauna changes}

There are 131 species in the modern mammal fauna of Ukraine, among them, there are 23 alien species $(17.6 \%)$. The initial fauna included 123 species, 15 of them became extinct during the last three centuries $(12.2 \%)$. The total list of species, which were known during the last three centuries, includes 146 species, among them there are 108 species of the «basal» list (unchanged part of species list). Some correlations between major species groups are presented in Table 6 .

\section{List of extinct species}

There are 15 extinct species, mainly from the groups Glires (6) and Ungulata (4).

- Glires (6 sp.): Leporiformes - Ochotona pusilla; Muriformes - Spermophilus "major" (=superciliosus: Popova, 2014), Marmota marmota, Pteromys volans, Eliomys quercinus (= phantom in modern fauna?), Pygeretmus pumilio.

- Lipotyphla (2 sp.): Soriciformes - Sorex satunini, Hemiechinus auritus (= phantom?).

- Chiroptera (1 sp.): Vespertilioniformes - Miniopterus schreibersii.

- Ferae (2 sp.): Caniformes — Monachus monachus (= phantom?), Gulo gulo.

- Ungulata (4 sp.): Cerviformes - Bos primigenius, Saiga tatarica, Rupicapra rupicapra, Bison bonasus (extinct in the wild, present only in captivity or seminatural conditions).

\section{List of alien species}

There are 23 alien species, mainly from the groups Ungulata (8), Glires (7), and Ferae (6) ${ }^{6}$.

- Glires (8 sp.): Leporiformes - Oryctolagus cuniculus; Muriformes - Mus musculus, Rattus rattus, Rattus norvegicus, Ondatra zibethicus, Lagurus lagurus, Myocastor coypus.

- Chiroptera (2 sp.): Vespertilioniformes - Plecotus austriacus, Pipistrellus kuhlii.

- Ferae (6 sp.): Caniformes - Felis catus, Nyctereutes procyonoides, Canis familiaris, Canis aureus, Neovison vison, Mustela eversmanni.

- Ungulata (8 sp.): Equiformes - Equus caballus, Cerviformes - Dama dama, Cervus nippon, Bos taurus, Bubalus bubalis, Capra hircus, Ovis musimon, Ovis aries.

\footnotetext{
${ }^{6}$ Cavia porcellus and Homo sapiens listed in previous review (2012) were excluded in the current review.
} 
Table 6. Number of main species groups in species lists of mammal superorders known in the fauna of Ukraine Таблиця 6. Кількість головних груп видів у списках надрядів ссавців, відомих у фауні України

\begin{tabular}{l|c|c|c|c|c|c|l}
\hline Superorder & $\begin{array}{c}\text { Initial } \\
(\text { ini })\end{array}$ & $\begin{array}{c}\text { Extinct } \\
(\text { ext })\end{array}$ & $\begin{array}{c}\text { Alien } \\
(a d v)\end{array}$ & $\begin{array}{c}\text { Modern } \\
(\mathrm{mod})\end{array}$ & $\begin{array}{c}\text { Complete } \\
\text { list CSL }\end{array}$ & $\begin{array}{c}\text { Phan- } \\
\text { tom }\end{array}$ & Index of Fauna Rotation \\
\hline Chiroptera & 27 & 1 & 2 & 28 & 29 & $(3)$ & IFR $=1 / 2(1+2) / 27=5.6 \%$ \\
Lipotyphla & 14 & 2 & 0 & 12 & 14 & $(2)$ & IFR $=1 / 2(2+0) / 14=7.1 \%$ \\
Glires & 51 & 6 & 7 & 52 & 58 & $(1)$ & IFR $=1 / 2(6+7) / 51=12.7 \%$ \\
Ferae & 17 & 2 & 6 & 21 & 23 & $(1)$ & IFR $=1 / 2(2+6) / 17=23.5 \%$ \\
Ungulata (s. 1.) & 14 & 4 & 8 & 18 & 22 & $(2)$ & IFR $=1 / 2(4+8) / 14=42.9 \%$ \\
Total & 123 & 15 & 23 & 131 & 146 & $(9)$ & IFR $=1 / 2(15+23) / 123=15.4 \%$ \\
\hline
\end{tabular}

$* \bmod =i n i-e x t+a d v ; C S L=i n i+a d v=\bmod +e x t ; I F R=[(e x t+a d v) / 2] / i n i * 100 \%$.

\section{List of phantom species}

There are 9 phantom species, mainly among Chiroptera (3), Lipotyphla (2) and Ungulata (2).

- Glires (1 sp.): Muriformes - Eliomys quercinus (completely extinct?).

- Lipotyphla (2 sp.): Soriciformes - Erinaceus europaeus (erroneous identification?), Sores isodon (erroneous identification?).

- Chiroptera (3 sp.): Vespertilioniformes - Tadarida teniotis, Rhinolophus euryale, Rhinolophus mehelyi (erroneous identification?).

- Ferae (1 sp.): Caniformes - Procyon lotor (absent?).

- Ungulata (2 sp.): Balaeniformes - Balaenoptera acutorostrata (vagrant specimens?), Cerviformes - Capreolus pygargus (erroneous identification?).

\section{Conclusion}

This study demonstrates significant changes in the mammal fauna of Ukraine during the last 300 years. There are four vectors of change, the first of which is analyzed in this paper, and the others were discussed in previous publications (Zagorodniuk, 2010 a etc.):

- Taxonomy component: the greatest changes are in the composition of macrofauna, especially ungulates (rotation index is $43 \%$ ) and carnivores (rotation index is $24 \%$ ), and the lowest changes are in insectivores and bats (rotation indices are 6-7\%);

- Geographic component: the greatest change is in the south and east of Ukraine which are the most transformed regions, particularly in the coastal areas in the steppe zone as well as in the "Grey Belt" of Donbas (14-20\%); in other regions IFR = 2-12\%;

- Temporal component: changes significantly grow over time, and they are the lowest when compared to the original reconstructed faunal list with the data on fauna composition for the early $20^{\text {th }}$ century (rotation index $1 \%$ ), but significantly increased in the second half of the $20^{\text {th }}$ century ( $3 \%)$ and changes are high at the beginning of the $21^{\text {st }}$ century $(15 \%)$;

- Scale effect: the changes are significant in local and regional faunas and they reach the values of about $45-50 \%$ at the level of local fauna assemblages (including fauna of nature reserves), they make up $12-27 \%$ at the level of administrative regions, and they not exceed $9-10 \%$ for the whole territory of Ukraine (Table 8).

In this regard, it is important to note that describing the state of fauna or its individual components now there is needed to discuss not only rare or alien species, but also the complete spatiotemporal dynamics of fauna, which affects each taxonomic and ecological groups of mammals. In this regard, it is relevant the Van Valen's idea that the success of a species in using of resources always leads to the total loss of all other species (Van Valen, 1973, 1976) ${ }^{7}$.

\footnotetext{
${ }^{7}$ He postulates the hypothesis of average constancy of total amount of competition (The Red Queen's hypothesis): "For any ultimately regulatory resource, what one species or individual gains, the rest lose" (Van Valen, 1973).
} 
Table 7. Indices of fauna changes (IFR) calculated for mammals of Ukraine as a whole as well as its some separate regions and local natural complexes

Таблиця 7. Показники змін фауни (IFR), розраховані для фауни ссавців України в цілому та ії окремих регіонів і локальних природних комплексів

\begin{tabular}{|c|c|c|c|c|}
\hline Region or period & Time scale & IFR & $\mathrm{IFR}_{100}$ & References \\
\hline \multicolumn{5}{|l|}{ Ukraine in a whole* } \\
\hline Data for the first third part of XX cent. & ini-list to 1938 & 0.6 & 0.2 & Zagorodniuk, 2010 a \\
\hline Data for the second third part of XX cent. & ini-list to 1965 & 2.6 & 0.9 & Zagorodniuk, 2010 a \\
\hline Data for the beginning of XXI cent. & ini-list to 2014 & 15.4 & 5.1 & this paper \\
\hline \multicolumn{5}{|l|}{ Natural zones level* } \\
\hline Carpathians (several districts) & ini-list to 2007 & $1.7-5.3$ & 1.8 & Zagorodniuk, 2007 b \\
\hline Polissia and Forest-Steppe zone & ini-list to 2007 & $7.2-9.9$ & 3.3 & Zagorodniuk, 2007 b \\
\hline Steppe zone (4 districts) & ini-list to 2007 & $14.0-20.4$ & 6.8 & Zagorodniuk, 2007 b \\
\hline \multicolumn{5}{|l|}{ Regional level } \\
\hline Central Podillia (mainly Vinnytsia Reg.) & since 1925 (90 yy.) & 10.8 & 12.0 & Zagorodniuk, Pirkhal, 2013 \\
\hline NE Ukraine (Slobozhanshchyna) & since 1853 (160 yy.) & 22.1 & 13.8 & Zagorodniuk, 2010 a \\
\hline Luhansk Region (easternmost region) & since 1963 (90 уy.) & 13.3 & 26.6 & Zagorodniuk, 2012 \\
\hline
\end{tabular}

\section{Local level}

Kamiani Mohyly Natural Reserve**

during last century

46.2

46.2 Zagorodniuk, 2007 a

* The author postulated the time of reconstructed species list as "period of Russ" (10 centuries ago) (Zagorodniuk, Emelyanov, 2008), but really this list should be referred to the period of last 2-3 centuries (Zagorodniuk, Emelianov, 2012); $\mathrm{IFR}_{100}$ calculated here by using the largest value for 3 centuries; ** data for only small mammals.

This species is the man (and also the species of domesticated mammals which bred by human, as well as alien synanthropic species). In this confrontation, all the wild species are losing, i. e. all species that depend on resources controlled by man. Similar effects are shown for many different regional faunas. Human influence often exceeds all other factors.

One of the most ambitious experiments conducted by man is the history of Australian fauna. It was shown that «All extinctions coincide with the colonization of the continent by aboriginal man. ... Large-bodied recent mammals are threatened by human hunting practices. ... The late Pleistocene extinctions were caused primarily by anthropogenic factors such as human hunting, whereas historical extinctions were due mostly to habitat alteration and exotic species introductions») (Lyons et al., 2004). This total redistribution of resources in favor of man leads to radical changes in natural faunal communities and causes their extremely rapid turnover. It is essential to note that well-known global turnovers described for the geological history of fauna outlined recently in the book «The Sixth Extinction» (Kolbert, 2014), and they are now taking place with renewed vigor.

The mammal fauna of Ukraine has become a good example of such changes. It is important that there are gradients of such changes listed above. At present, there are 15 extinct, 23 alien and 9 phantom species in the mammal fauna of Ukraine. Each of these figures is the "normal" composition for some local fauna, and their sum (47 species) is equal to a "normal" number of mammal species in typical regional fauna ${ }^{8}$. Nevertheless, this figure is abnormal part of diversity, and the aboriginal "portion" of mammal fauna can appear in minority in the nearest future.

It is possible to evaluate the factors of changes as well as the conditions for great or minor transformations of fauna. Such analysis may be the key to ongoing change management processes. The most important task should be the detailed mapping of large areas to determine the spatial structure of faunal assemblages using the criterion of their transformation. To some extent species such mapping is the reverse side of the model, which defines the "hot spots" of biodiversity.

\footnotetext{
${ }^{8}$ For ex., mammal fauna of the Luhansk Reg. includes 53 (Sakhno, 1963) to 67 species (Zagorodniuk, 2012). Fauna of Central Podillia is relatively richness: initial list of the fauna (reconstruction after: Khranevych, 1923) includes 74 species, among them 6 species extinct, but 10 new species appeared (Zagorodniuk, Pirkhal, 2013).
} 


\section{Acknowledgements}

Investigation was conducted in the framework of the project "Modern state of mammal fauna and its long-year changes in Ukraine" (State registration in Ukraine № 0112U005504, 2012-2016). The author thanks Alex Zagorodniuk, Pavel Goldin and Zoltan Barkasi for language proofreading.

\section{References}

Amrine-Madsen, H., Koepfli, K.-P., Wayne, R. K., Springer, M. S. A new phylogenetic marker, apoliprotein B, provides compelling evidence for eutherian relationships // Molecular Phylogenetics and Evolution. — 2003. Vol. 28. - P. 225-240.

Asher, R. J., Bennett, N., Lehmann, T. The new framework for understanding placental mammal evolution // BioEssays. - 2009. - Vol. 31. - P. 853-864.

Bobrov, V. V., Warshavsky, A. A., Khlyap, L. A. Alien mammals in the ecosystems of Russia. - Moscow : KMK Scientific Press Ltd., 2008. — 232 p. — ISBN 978-5-87317-487-4. (In Russian; English summary).

Convention on Biological Diversity. — www.cbd.int. - 1992-2014.

Dulitskiy, A. I. Biodiversity of the Crimea. Mammals : History, State, Protection, Perspectives. - Simpheropol : SONAT Press, 2001. - 208 p. - ISBN 966-7347-52-4. (In Russian).

Dulitskiy, $A$. The real and virtual elements in the dynamics of fauna list of Crimean mammals // Proceedings of the Theriological School. — Luhansk, 2010. — Vol. 10 (Monitoring of Mammal Fauna). — P. 53-64. (In Russian; English summary).

Dulitskiy, A. I., Mikhailova, A. E., Stenko, R. P. The first finds of the Mehely's and the Southern horseshoe bats (Rhinolophus mehelyi Matschye, 1901 and Rh. euryale Blasius, 1853; Chiroptera, Rhinolophidae) on the territory of Ukraine // Reserves of the Crimea at the Turn of the Millennium. - Simferopol, 2001. — P. 32-33. (In Russian).

Gladilina, E. V., Kovtun, O. A., Kondakov, A. A. Grey seal Halichoerus grypus in the Black Sea: the first case of longterm survival of an exotic pinniped // Marine Biodiversity Records. - 2013. — Vol. 6, e33. - P. 1-6.

Godlevskaya, E. V. Expansion of Plecotus austriacus (Chiroptera, Vespertilionidae) range: first records in Kiev Oblast (Ukraine) // Vestnik zoologii. — 2012. — Vol. 46, № 1. - P. 88.

Khranevych, V. Mammals of Podillia. Systematic Review. — Vinnytsia : Vinderzhdruk, 1925. — 31 p. (In Ukrainian).

Kryzhanovsky, V. I., Emelianov, I. G. Class of mammals // V. A. Topachevski (ed). Nature of Ukrainian SSR. Animal World. - Kyiv : Naukova Dumka, 1985. - P. 197-234. (In Russian).

Kirikov, S. V. Hunting Animals, Natural Environment, and Man. — Moskva : Nauka, 1966. — 248 p. (In Russian).

Kirikov, S. V. Man and Nature of Steppe Zone. End of X to Middle of XIX Century (European part of USSR). Moskva : Nauka, 1983. - 126 p. (In Russian).

Kolbert, E. The Sixth Extinction: An Unnatural History. — New York: Henry Holt and Co., 2014. — ISBN 9780805092998. — http://goo.gl/EX3MD8

Korneyev, O. O. Key to mammals of U[krainian]RSR. (2 ${ }^{\text {nd }}$ ed.). - Kyiv : Naukova Dumka Press, 1965. — 236 p. (In Ukrainian).

Lyons, S. K., Smith, F. A., Brown, J. H. Of mice, mastodons and men: human-mediated extinctions on four continents // Evolutionary Ecology Research. — 2004. — Vol. 6 (3). — P. 339-358.

McKenna M. C., Bell S. K. Classification of mammals above species level. - New York: Columbia University Press, 1997. - XII + $631 \mathrm{p}$.

Mezhzherin, $S$. V. Discovery of new for Ukraine species of brown-toothed shrews Sorex sp. (Insectivora, Soricidae) // Vestnik zoologii. - 1995. - N 5-6. - P. 17.

Panov, G. Dynamics of ranges and of abundances of semi-water fur-bearing mammals in Ukraine during second part of the $20^{\text {th }}$ century // Visnyk of the Lviv University. Biology Series. - 2002. — Issue 30. — P. 119-132. (In Ukrainian; English summary).

Parnikoza, I., Sesin, V., Boreiko, V. History, current state and perspectives of conservation of European bison (Bison bonasus L.) in Ukraine // Proceedings of the Theriological School. — 2010. — Vol. 10 (Monitoring of mammal fauna). - P. 137-149. (In Ukrainian; English summary).

Pidoplichko, I. G. Time of extinction of the steppe pika in the South of USSR // Priroda [Nature (Moscow)]. 1934. - N 12. - P. 78-80. (in Russian).

Pidoplichka, I. G. Modern nature and origin of mammal fauna of Ukr. RSR // Zbirnyk Prats Zool. Mus. - Kyiv, 1936. - № 18. — P. 3-28. — (Trudy Inst. Zool. and Biol., Acad. Sci. Ukr. SRR; Vol. 13). (In Ukrainian).

Pidoplichko, I. G. The Glacial Period. - Kyiv : AN Ukr. SSR Press, 1951. — Issue 2. — 264 p. (in Russian).

Plakhina, D. A., Zvychaynaya, E. Yu., Kholodova, M. V., Danilkin, A. A. Identification of European (Capreolus capreolus L.) and Siberian (C. pygargus Pall.) roe deer hybrids by microsatellite marker analysis // Russian Journal of Genetics. — 2014. — Vol. 50, No. 7. — P. 757-762. 
Polishchuk, I. K. Changes in theriofauna of reserve "Askania Nova" for the 100 -year period // Theriofauna Russia and Adjacent Territories (VII Meeting of Theriological Society). — Moscow, 2003. — P. 271. (In Russian).

Polishchuk, I. K. Historical changes in the population of amphibians, reptiles and small mammals of the Biosphere reserve "Askania Nova" // News Biosphere Reserve "Askania-Nova". — 2008. — Vol. 10. — P. 90-102. (In Ukrainian).

Popova, L. V. Small mammal fauna as an evidence of environmental dynamics in the Holocene of Ukrainian area // Quaternary International. — 2014 (2015). — Vol. 357. — P. 82-92. — http://goo.gl/rKEdyz

Protasov, A. A. Biodiversity and Its Estimation. Conceptual Diversicology / Inst. Hydrobiology NAS of Ukraine. Kyiv, 2002. - 105 p. - ISBN 966-02-2517-2. (In Russian).

Red Data Book of Ukraine / Ed. by I. A. Akimov. - Kyiv : Global Consulting Press, 2009. — 624 p.

Rozhenko, N. V., Volokh, A. M. Appearance the golden jackal (Canis aureus) in the South of Ukraine // Vestnik Zoologii. - 2000. - Vol. 34, N 1-2. — P. 125-129. (In Russian).

Roženko, N., Volokh, A. The golden jackal (Canis aureus L., 1758) as a new species in the fauna of Ukraine // Beiträge zur Jagd und Wildforschung. — 2010. — Bd. 35. - S. 237-246.

Sakhno, I. I. To study the mammal and bird fauna of shelter belts in Odesa and Mykolaiv regions and the impact of fauna on the surrounding field // Zbirnyk Prats Zool. Mus. / Inst. Zool. and Biol., Acad. Sci. Ukr. RSR. — 1938. - N 21/22. - P. 97-138. (In Ukrainian).

Sakhno, I. I. Brief review of mammal fauna of the Luhansk Region // Reports and Communications ... for 1962 / Luhansk State Pedagogical University. Fiz.-Math. and Nat.-Hist. Faculties. — Luhansk, 1963. — P. 49-54.

Sakhno, I. I. Changes in mammal composition in the Luhansk Oblast // Lets Protect the Native Nature [Okhraniaite rodnuiu prirody]. — Donetsk : Donbas Press, 1969. — Issue 2. - P. 114-123. (In Russian).

Sakhno, I. I., Symonov, M. A. Results of acclimatization of the game mammals in Voroshilovgrad Region // Naukovi Zapysky / Voroshilovgrad Pedagogical Institute. Series of Physics and Mathematics and Natural History Sciences. - 1956. - Issue 6. - P. 16-30. (In Ukrainian).

Shevchenko, S. Long-eared hedgehog (Hemiechinus auritus) in Ukraine: a review // Proceedings of the Theriological School. - 2008. - Vol. 9 (Rare Theriofauna and Its Conservation). — P. 250-258. (In Ukrainian; English summary).

Sokur, I. T. Historical Changes and Use of Mammal Fauna of Ukraine. - Kyiv : Ukr. Acad. Sci. Press, 1961. 84 p. (In Ukrainian).

Uhrin, M., Gazaryan, S., Benda, P. Does Tadarida teniotis really occur in Crimea? (Chiroptera: Molossidae) // Lynx, n. s. (Praha). - 2009. - Vol. 40. - P. 115-126.

Van Valen, L. A new evolutionary law // Evol. Theory. - 1973. — Vol. 1. — P. 1-30. — http://bit.ly/1X0KQGu

Van Valen, L. Energy and evolution // Evolutionary Theory. — 1976. — Vol. 1, N 7. — P. 179-229. — http://bit.ly/1LFPR6o

Vishnevskiy, D., Kotlyarov, O. Estimations of large mammal species abundance in the Chernobyl Exclusion Zone: an analysis of different sources of data // Proceedings of the Theriological School. — Luhansk, 2008. — Vol. 9 (Rare Theriofauna and Its Conservation). - P. 21-27. (In Ukrainian; English summary).

Wilson, D. E., Reeder, D. M. (eds.). Mammal Species of the World. - Baltimore: Johns Hopkins Univ. Press, 2005. - 2142 p. - ISBN 978-0-8018-8221-0. — http://www.bucknell.edu/msw3/.

Yasinetskaya, N. I., Zharkikh, T. L. The onager (Equus hemionus) in Ukraine // Theriofauna of Russia and adjacent territories (VII Meeting of Theriological Society). - Moskva, 2003. - P. 399-400. (In Russian).

Zagorodniuk, I. Rare shrew species in the territory of Ukraine: legends, facts, and diagnostics // Vestnik Zoologii. 1996. - Vol. 30 (6). - P. 53-69. (In Russian; English summary).

Zagorodniuk, I. V. Changes in ungulate fauna of Ukraine during the historical time // Vestnik Zoologii. — 1999. Suppl. N 11. - P. 91-97. - (Proceedings of the VI International Symposium of the Preservation of the Przewalski Horse). (In Ukrainian; English summary).

Zagorodniuk, I. Composition and historical changes of carnivore fauna of Ukraine // Large Carnivore Mammals of Ukraine and Adjacent Countries. — Kyiv, 2001. — P. 14-17. — (Novitates Theriologicae; Pars 4). (In Ukrainian; English summary).

Zagorodniuk, I. Allospecies of the roe deer (Capreolus): nature of differences between them and status of populations from Ukraine // Visnyk of the Luhansk Pedagogical University. Biological Sciences. — 2002. — N 1 (45). P. 206-222. (In Ukrainian; English summary).

Zagorodniuk, I. Biogeography of mammals' cryptic species in the Eastern Europe // Scientific Bulletin of the Uzhgorod University. Series Biology. - 2005. - Issue 17. - P. 5-27. (In Ukrainian; English summary).

Zagorodniuk, I. Adventive mammal fauna of Ukraine and a significance of invasions in historical changes of fauna and communities // Proceedings of the Theriological School. — Luhansk, 2006. - Vol. 8 (Fauna in Anthropogenic Environments). - P. 18-47. (In Ukrainian; English summary).

Zagorodniuk, I. Small mammals of the natural reserve "Kamiani Mohyly": analysis of fauna composition and historical changes of communities // Visnyk of Lviv University: Biology Series. — 2007 a. — Is. 44. — P. 71-79. (In Ukrainian; English summary). 
Zagorodniuk, I. Mammals of Ukraine: geographical and historical changes of fauna and communities diversity // Biodiversity and Role of Animals in Ecosystems: Extended abstracts of the IV International Conference «Zoocenosis-2007». - Dnipropetrovsk : Dnipropetrovsk University Press, 2007 b. - P. 479-482. (In Ukrainian).

Zagorodniuk, I. Scientific names of mammal orders: from descriptive to uniform // Visnyk of Lviv University. Biology series. - 2008. — Is. 48. - P. 38-48. (In Ukrainian; English summary).

Zagorodniuk, I. V. Taxonomy and nomenclature of the non-Muroidea rodents of Ukraine // Proceedings of Zoological Museum. - Kyiv, 2009. - N 40. - P. 147-185. (In Ukrainian; English summary).

Zagorodniuk, I. V. Mammal of the North-Eastern Ukraine: changes of fauna and views about fauna composition since review by Ol. Czernay (1853) to the present. Communication 2 // Proceedings of the National Museum of Natural History. - Kyiv, 2010 a. - Vol. 8. - P. 33-60. (In Ukrainian; English summary).

Zagorodniuk, I. Cryptic diversity and changes of views on mammal fauna composition // Proceedings of the Theriological School. - Luhansk, 2010 b. - Vol. 10 (Monitoring of Mammal Fauna). - P. 13-27. (In Ukrainian; English summary).

Zagorodniuk, I. Mammals of the Eastern Ukraine: changes in species list and abundance since I. Sakhno review (1963) to now // The Journal of V. N. Karazin Kharkiv National University. Series: Biology. - 2012. Vol. 16 (№ 1035). - P. 97-108. (In Ukrainian; English summary).

Zagorodniuk, I. Golden jackal (Canis aureus) in Ukraine: modern expansion and status of species // Proceedings of the National Museum of Natural History. - 2014. - Vol. 12. - P. 100-105.

Zagorodniuk, I., Emelyanov, I. Cryptic diversity of mammals in Eastern Europe as reflection of variety of species phenomena // Scientific Bulletin of the Uzhgorod University. Series Biology. — 2008. — Vol. 22. — P. 166178. (In Ukrainian; English summary).

Zagorodniuk, I. V., Emelianov, I. G. Taxonomy and nomenclature of mammals of Ukraine // Proceedings of the National Museum of Natural History. - 2012. - Vol. 10. - P. 5-30. (In Ukrainian; English summary).

Zagorodniuk, I., Korobchenko, M. Rare fauna of eastern Ukraine: composition and distribution of rare species // Proceedings of the Theriological School. - 2008. - Vol. 9 (Rarity mammal fauna and its protection). P. 107-156. (In Ukrainian; English summary).

Zagorodniuk, I., Negoda, V. Pipistrelle bats of the genus Pipistrellus and genus Hypsugo // Migration Status of Bats in Ukraine. - Kyiv, 2001. - P. 65-72. - (Novitates Theriologicae; Pars 6). (In Ukrainian; English summary).

Zagorodniuk, I., Pirkhal, A. Mammals of Podillia: taxonomy and changes of fauna composition during last century // Proc. of the State Nat. Hist. Museum. - Lviv, 2013. - Vol. 29. - P. 189-202. (In Ukrainian; English summary).

Zagorodniuk, I., Rizun, $V$. Dynamics of biodiversity as concept (to 20 anniversary of Convention of Biological Diversity) // Dynamics of Biodiversity 2012. — Luhansk : Luhansk Natl. Univ. Press, 2012. - P. 12-17. — ISBN 978-966-617-297-9. (In Ukrainian).

Zagorodniuk, I. V., Tkach, V. V. The present state of fauna and the historical changes of abundance of the bats (Chiroptera) in the territory of Ukraine // Reports Natl. Acad. Sci. Ukr. — 1996. - N 5. - P. 136-142. (In Ukrainian; English summary).

Zagorodniuk, I., Godlevska, L., Tyshchenko, V., Petrushenko, Ya. Bats of Ukraine and adjacent countries: a guide for field investigations. - Kyiv, 2002. - 110 p. - (Series: Proceedings of the Theriological School; Vol. 3). ISBN 966-02-2476-1. (In Ukrainian, English summary). 